\title{
Use of single superphosphate fertiliser produced using Eppawala rock phosphate as a source of phosphorous for rice cultivation
}

\author{
CP Udawatte ${ }^{*}$, PVA Panagoda ${ }^{2}$, WMADB Wickramasinghe ${ }^{3}, J^{2}$ Wijewardena ${ }^{4}$, DN Sirisena $^{5}$, \\ S Emitiyagoda ${ }^{6}$ and HRUD Bandara ${ }^{7}$ \\ ${ }^{1}$ Department of Physical Science and Technology, Faculty of Applied Sciences, Sabaragamuwa University of Sri Lanka, Belihuloya. \\ ${ }^{2}$ Department of Earth Resource Engineering, Faculty of Engineering, University of Moratuwa, Moratuwa. \\ ${ }^{3}$ Rice Research and Development Institute, Batalagoda, Ibbagamuwa. \\ ${ }^{4}$ Sri Lanka Council for Agricultural Research Policy, Wijerama Mawatha, Colombo 07. \\ ${ }^{5}$ Horticulture Crop Research and Development Institute, Gannoruwa, Peradeniya. \\ ${ }^{6}$ Extension and Training Centre, Department of Agriculture, Peradeniya. \\ ${ }^{7}$ Lanka Phosphate Limited, Eppawala.
}

\begin{abstract}
Sri Lanka is an agricultural country totally depending on imported fertilisers for paddy cultivation. Importation of fertilisers including triple superphosphate (TSP) is a heavy burden on the country's national economy. Hence, optimum utilisation of the locally available Eppawala phosphate deposit (EPD) will save a significant amount of foreign exchange. The objective of this study was to assess the effectiveness of locally produced Eppawala single superphosphate (ESSP) as a source of phosphate fertiliser for rice in comparison to TSP. Small tonnage of ESSP was produced for the purpose of experiments using finely ground Eppawala rock phosphate (ERP: $90 \%<150 \mu \mathrm{m}$ ) mixed with $70 \%$ sulphuric acid stoichiometrically, allowing the resulting slurry to solidify. Resulting product granulated after curing for 2-3 weeks was characterised by X-ray fluorescence (XRF), $\mathrm{X}$-ray powder diffraction (XRD) and the available phosphorus was determined. The available phosphorus was found to be in the range of $20-22 \%$, which is far in excess of the stipulated requirement of $17 \%$. Agronomic effectiveness of ESSP over the imported TSP was tested for rice cultivation in different soil conditions in the dry, wet and intermediate zones of Sri Lanka in five consecutive seasons. The results showed that important parameters such as the grain yield and root dry weight in plots applied with ESSP as a source of phosphorus were comparable with that of TSP applied plots. Application of TSP and ESSP showed similar results in dry and intermediate zones of the country. Therefore, if ESSP is produced in sufficient quantities
\end{abstract}

the importation of TSP could be reduced without much effect on agronomic effectiveness for rice cultivation.

Keywords: Agronomic effectiveness, ESSP, rice, TSP.

\section{INTRODUCTION}

Phosphorus $(\mathrm{P})$ is one of the most important plant nutrients in rice cultivation. Continuous cultivation of high yielding rice varieties has resulted in a decline in the ability of soil to provide the adequate $\mathrm{P}$ requirement (Senanayake 1984, Sirisena et al., 2000, Wickramasinghe et al., 2000, Seneviratne et al., 2002). Therefore, application of $\mathrm{P}$ as fertiliser is important to maintain soil fertility (Rezania, 1992). At present, triple superphosphate (TSP) is the major source of $\mathrm{P}$ fertiliser recommended by the Department of Agriculture (DOA) by the 2000 recommendations for rice in Sri Lanka with nearly $80 \%$ of the total imported TSP used in the paddy sector alone (Hemachandra et al., 1988, Wijewardena et al., 1990; 1998, Wijewardena 1998, 1999). The country's annual requirement of TSP is imported at a cost of nearly Rs. 6.5 billion (NFS, 2018). Experiments have been conducted during the past four decades to investigate the suitability of Eppawala rock phosphate (ERP) in different forms as a $\mathrm{P}$ fertiliser for

\footnotetext{
*Corresponding author (chand@appsc.sab.ac.lk; (10) https://orcid.org/0000-0003-1723-7816)
} 
rice cultivation. Nagarajha et al. (1979; 1980), Maraikar et al. (1983) and Joseph (1986) have tested concentrated superphosphate (CSP), Rhenania phosphate (RhP), fused magnesium phosphate (FMP), Eppawala rock phosphate (ERP) and imported rock phosphate (IRP) as sources of $P$ for rice. Long-term experiments have shown that there is hardly any residual or cumulative effect of ERP while IRP showing slightly better results. The effect of RhP and CSP however, were very significant. It was viewed that the better performance of RhP and FMP could be partly due to their silicate content. Wijesundara et al. (1993) and Wickramasinghe et al., (unpublished data; Annual Report, RRDI) reported that rice showed no response to FMP, but a significant response to di-ammonium phosphate in intermediate and dry zones of Sri Lanka. Ratnayake et al., (1994) reported that TSP is the best source of $\mathrm{P}$ fertiliser than selectively mined Eppawala rock phosphate (SERP) or high grade Eppawala rock phosphate (HERP) and ERP. However, the increase in plant $\mathrm{P}$ uptake was higher in SERP treated soils than ERP. Although SERP/HERP has a total $\mathrm{P}_{2} \mathrm{O}_{5}$ content in the range of 30 to $40 \%$, citric acid soluble $\mathrm{P}_{2} \mathrm{O}_{5}$ is only $5.8 \%$.

ERP's low solubility prevented its use in short-term food crops. However, performance of SSP produced from ERP over that of TSP in the food crop sector has not been reported yet. Since the nature of the Eppawala apatite deposit favours the production of SSP as reported by NSF (1999), a research programme was launched as per the recommendations of the report.

The manufacturing process of ESSP consists of reacting finely-ground phosphate rock with conc. sulfuric acid, resulting ESSP containing $18 \% \mathrm{P}_{2} \mathrm{O}_{5}$.

The net reaction is given below:

$$
\begin{array}{ll}
\mathrm{Ca} \mathrm{F}_{2} \cdot 3 \mathrm{Ca}_{3}\left(\mathrm{PO}_{4}\right)_{2}+\rightarrow & 3 \mathrm{Ca}\left(\mathrm{H}_{2} \mathrm{PO}_{4}\right)_{2}+7 \mathrm{CaSO}_{4} \cdot 2 \mathrm{H}_{2} \mathrm{O} \\
7 \mathrm{H}_{2} \mathrm{SO}_{44}+14 \mathrm{H}_{2} \mathrm{O} & +2 \mathrm{HF}
\end{array}
$$

The process takes place in two stages as follows:

The first stage represents the diffusion of sulfuric acid in the ground rock mass accompanied by a rapid chemical reaction on the particle surface, continuing until the acid is completely consumed with the crystallisation of calcium sulphate.

The second stage represents the diffusion of the formed phosphoric acid into the pores of the rock particles which did not decompose. This stage is accompanied by a second reaction. This reaction ends in the reaction mixer in 30-60 minutes, during the period of settling and hardening of the superphosphate slurry caused by the relatively rapid crystallisation of the low solubility calcium sulphate. The next stage is the ageing of the superphosphate, i.e. the formation and crystallisation of monocalcium phosphate. The end product still containing a certain amount of uncombined phosphoric acid makes the fertiliser more hygroscopic, although it is not a serious disadvantage. However, the hydroscopic nature of the product may be minimised by subsequent treatment of the product with ammonia or ammonium sulphate. This may be carried out prior to and after the curing period.

The objective of this research was to assess the effectiveness of locally produced Eppawala single super phosphate fertiliser for rice in comparison with triple super phosphate.

\section{METHODOLOGY}

A limited quantity of Eppawala single superphosphate (ESSP) produced from ERP by Lanka Phosphate Limited (LPL) was evaluated for its agronomic efficiency for rice at the Rice Research and Development Institute, Batalagoda and Regional Agriculture Research and Development Centre, Bombuwala. After conducting the initial experiments, the study was extended to farmer fields in Polonnaruwa and Kalutara districts. The adaptability of ESSP was tested in 146 farmer fields distributed island-wide with varying soil conditions in collaboration with the Department of Agriculture (DOA), Provincial Departments of Agriculture (PDOA) and the Mahaweli Authority of Sri Lanka.

\section{Preparation of Eppawala single superphosphate (ESSP)}

The commercial product, ERP $\left(28 \%\right.$ wt. $\left.\mathrm{P}_{2} \mathrm{O}_{5}\right)$ of Lanka Phosphate Limited is manufactured by crushing and grinding the run-of-quarry (ROQ) phosphate to $<100 \mu \mathrm{m}$ powder form using roller mills (SLS-645). The powder was well mixed with commercially available conc. $\mathrm{H}_{2} \mathrm{SO}_{4}$ according to the ratio of $100 \mathrm{~kg}$ of ERP: $2000 \mathrm{~cm}^{3}$ of $70 \% \mathrm{H}_{2} \mathrm{SO}_{4}$ by manually pouring the acid straight from the plastic container and stirring portion-by-portion for 30 mins in a stainless steel vessel fixed with a blender operated at $10 \mathrm{rpm}$ throughout its preparation. Twenty tonnes (20 t) of ESSP were produced in batches with each batch producing one tonne of the mixture. The resultant slurry was allowed to cool and stand at room temperature for one month for curing followed by sun drying and grinding to obtain ESSP in powder form $(100 \mu \mathrm{m})$. 
The available $\mathrm{P}_{2} \mathrm{O}_{5}$ content of the starting ERP and the resulting ESSP were measured by the Vanodomolybdate method (Jaffery, 1971). The experimental procedure started taking $1 \mathrm{~g}$ of the sample into a $50 \mathrm{~mL}$ conical flask and adding $25 \mathrm{~mL}$ of $2 \%$ citric acid followed by stirring for $30 \mathrm{~min}$. The resultant suspension was filtered through No. 40 Watmann filter paper with $1 \mathrm{~cm}^{3}$ of the filtrate diluted to $100 \mathrm{~cm}^{3}$. The phosphate concentration in the solution was determined colorimetrically (ModelCorning-252) at $460 \mathrm{~nm}$ wavelength.

Chemical analysis of ERP and ESSP was conducted with X-ray fluorescence technique (Model Rigaku NEXCG, USA), with a beam diameter of $1 \mathrm{~mm}$ and an X-ray energy level of 8-10 keV. Phases present in the ERP and the resulting ESSP were determined using a Siemens D5000 powder $\mathrm{x}$-ray diffractometer with $\mathrm{Cu}-\mathrm{K}_{\alpha}$ radiation generated at $40 \mathrm{kV}$ and $30 \mathrm{~mA}$.

\section{Field experiments of Eppawala single superphosphate}

\section{Field experiment at RRDI at Batalagoda}

A long-term experiment was initiated in the Maha 2003/2004 season at the RRDI, Batalagoda to evaluate the performance of ESSP in comparison with TSP. Soil of the experimental site was a low humic gley soil (Batalagoda series) with sandy loam texture. Plot size was $6 \mathrm{~m} \times 3 \mathrm{~m}$. Treatments were arranged in accordance with randomised complete block design (RCBD) with three replications.

The four treatments of the experiment were: $(45 \mathrm{~kg}$ $\mathrm{P}_{2} \mathrm{O}_{5} /$ ha as TSP is the recommended level of P for dry zone and intermediate zone at that time - DOA 2003 fertiliser recommendation for rice)

$\mathrm{P0}$ - Control (no P fertiliser)

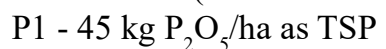

$\mathrm{P} 2$ - $45 \mathrm{~kg} \mathrm{P}_{2} \mathrm{O}_{5} / \mathrm{ha}$ as ESSP

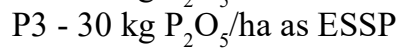

At the beginning of the experiment, composite soil samples from each replicate were tested for initial $\mathrm{P}$ content. All the plots received N, K and Zn (140 kg N, $40 \mathrm{~kg} \mathrm{~K} 2 \mathrm{O}$ and $1 \mathrm{~kg} \mathrm{Zn} / \mathrm{ha}$ ) at the rates recommended by the DOA in its 2003 fertiliser recommendations. P treated plots received respective $P$ treatments and applied as basal. Eighteen days old seedlings of the variety $\mathrm{Bg}$ 358 were transplanted at the spacing of $15 \mathrm{~cm} \times 15 \mathrm{~cm}$ at two plants per hill. Pest, diseases and weed management, and other cultural practices were done as recommended by the DOA. At the time of maturity, plant samples were collected from 10 hills and yield components and dry weights were measured. Air dried samples were used for the determination of plant $\mathrm{P}$ content. Plots were harvested at maturity after discarding the border rows. Grains were separated and air dried to calculate the plot yield at $14 \%$ moisture content. Experiment was continued in the Yala 2004, Maha 2004/2005, Yala 2005 and Maha 2005/2006 seasons.

\section{Field experiments at Polonnaruwa}

Since promising results were observed at RRDI, Batalagoda, similar experiments with the same treatments were conducted at 3 locations (Jayanthipura, Thopawewa and Higurakgoda) in the Polonnaruwa District in Maha 2004/2005 season.

Treatments comprised:

P0 - Control (no P fertiliser)

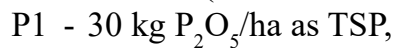

$\mathrm{P} 2$ - $45 \mathrm{~kg} \mathrm{P}_{2} \mathrm{O}_{5} /$ ha as TSP,

$\mathrm{P} 3$ - $30 \mathrm{~kg} \mathrm{\textrm {P } _ { 2 }} \mathrm{O}_{5} / \mathrm{ha}$ as ESSP,

$\mathrm{P} 4$ - $45 \mathrm{~kg} \mathrm{P}_{2} \mathrm{O}_{5} /$ ha as ESSP.

Land preparation and cultural practices were similar to the experiment conducted at RRDI, Batalagoda. Plots with the dimensions $6 \mathrm{~m} \times 3 \mathrm{~m}$ were arranged in accordance with RCBD with 3 replicates. Rice variety $\mathrm{Bg} 300$ was direct seeded. All the plots received N, K and Zn (140 kg $\mathrm{N}, 40 \mathrm{~kg} \mathrm{~K}_{2} \mathrm{O}$ and $1 \mathrm{~kg} \mathrm{Zn}$ ) at the rates recommended by the DOA. P treated plots received respective $P$ treatments and was applied as basal. At the time of maturity, plant samples were collected from $900 \mathrm{~m}^{2}$ area and yield components and dry weight of plants were measured. Air dried samples were used for the determination of plant $\mathrm{P}$ content. Plots were harvested in a similar manner followed at the RRDI experiment.

\section{Field experiments in low country wet zone (LCWZ)}

\section{Experiment 1}

Field experiments were conducted at 3 locations in the low country wet zone (LCWZ), namely, at the Regional Agriculture Research and Development Centre (RARDC), Bombuwala (location 1) and at two locations in farmers' fields in Palayangoda (location 2) and Keenagasmanana (location 3) in Maha 2004/2005 season.

Treatments of the experiment in all locations consisted of $30 \mathrm{Kg} \mathrm{P}_{2} \mathrm{O}_{5} /$ ha as per the recommended $\mathrm{P}$ level for wet zone, in 2003 DOA. 
P0 - Control (no P fertiliser)

$\mathrm{P} 1$ - $30 \mathrm{~kg} \mathrm{P}_{2} \mathrm{O}_{5} / \mathrm{ha}$ as TSP,

$\mathrm{P} 2$ - $7.2 \mathrm{~kg} \mathrm{P}_{2} \mathrm{O}_{5} /$ ha as ESSP,

P3 - $10.8 \mathrm{~kg} \mathrm{P}_{2} \mathrm{O}_{5} /$ ha as ESSP,

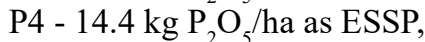

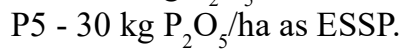

The treatments were arranged in a RCBD with three replicates, with the plot size of $6 \mathrm{~m} \times 3 \mathrm{~m}$. N and $\mathrm{K}$ were applied according to the DOA recommendation of 55 $\mathrm{kg} / \mathrm{ha}$ and $60 \mathrm{~kg} / \mathrm{ha}$, respectively. Rice variety Ld-356 was grown as a test crop. Soil samples were collected from each replicate before the commencement of the experiment and from each plot after each season in all 3 locations for analysis. Available P was analysed by Olsen's method. Ten (10) plants per each plot were uprooted at 45 days after planting and the root dry weight and root length were measured.

\section{Experiment 2}

A long-term field experiment was initiated at the RARDC, Bombuwala in 2006. The treatments consisted of : No P, T1 - ERP, T2 - HERP, T3 - ESSP, T4 - TSP and T5 - $50 \%$ TSP + $50 \%$ HERP. The experiment was laid out in a RCBD and replicated three times. The level of $\mathrm{P}$ was kept constant at the rate of $30 \mathrm{~kg} \mathrm{P}_{2} \mathrm{O}_{5} / \mathrm{ha}$ as recommended by the DOA for rice grown in the LCWZ. $\mathrm{N}$ and $\mathrm{K}$ were added to every treatment according to the rates and times recommended by the DOA. The plot size was $4.5 \mathrm{~m} \times 4.5 \mathrm{~m}$ and rice variety $\mathrm{Ld} 356$ was grown as a test crop. The respective treatment plots were maintained the same during the entire experimental period. Soil samples were collected from each replicate before commencement of the experiment and from each plot after each season for analysis. In addition, 10 plants from each plot were uprooted 45 days after planting and dry weight of foliage, dry weight of roots and root length were determined.

\section{Pilot scale farmer field demonstrations}

In the final stage of the series of experiments, pilot scale farmer field demonstrations were conducted in Maha 2004/2005 season at 146 locations (Kurunegala 5, Puttlam 5, Anuradhapura 50, Eppawala 10, Kalutara 5, Ratnapura 5, Udawalawa Mahaweli-5, Monaragala- 5, Ampara 5, Trincomalee 5, Hambanthota 5, Kandy 5, Minipe-Hasalaka-5, Mahaweli C, B, H-15, Gampaha-5 Galle-6, Kegalle-5) in 12 districts and in 5 major irrigation schemes covering all the agro-ecological zones and soil types in the country. Rice varieties selected for the experiments varied from location to location and were on the basis of farmer preference. Fertiliser rates were applied as recommended by the DOA for the respective agro-ecological zone. Testing was carried out in large plots $\left(1000 \mathrm{~m}^{2}\right)$ in adjacent fields. Phosphorus was applied as basal at the rate of $45 \mathrm{~kg} \mathrm{P}_{2} \mathrm{O}_{5} / \mathrm{ha}$ in the form of TSP and ESSP for respective plots. Plots were harvested at maturity and the grain yield was recorded at $14 \%$ moisture content.

\section{RESULTS AND DISCUSSION}

\section{Characterisation of ERP and ESSP}

It was noted that the powdered phase is not suitable for field application since it is partly blown away with the wind. However, this loss can be overcome by granulation or palletisation in the manufacturing process.

The XRF analysis of average $\mathrm{CaO}$ and $\mathrm{P}_{2} \mathrm{O}_{5}$ of run-of-Quarry apatite sample of ERP and ESSP shows 49.40 wt. $\%, 27.80$ wt. $\%$ and 66.30 wt.\%, 18.01 wt.\% respectively. Analysis did not indicate any significant presence of $\mathrm{Cd}$ and As in Eppawala Rock Phosphate. However, it was noted that the $\mathrm{Fe}$ and $\mathrm{Al}$ content in Sri Lankan apatite is considerably higher (as $\mathrm{Fe}_{2} \mathrm{O}_{3}$ 9.10 wt. $\%, \mathrm{Al}_{2} \mathrm{O}_{3} 5.90$ wt.\%, respectively) than the reported values in other countries (Jayawardena, 1988). Further, analysis of ESSP showed that it contains 22.40 wt.\% S, an added advantage for crop production.

The major element in ERP was $\mathrm{Ca}$ within a range of $21.5-24.5 \mathrm{wt} \%$. ERP contains apatite $\left[\mathrm{Ca}_{5}\left(\mathrm{PO}_{4}\right)_{3} . \mathrm{OH}, \mathrm{F}, \mathrm{Cl}\right]$ as the main constituent mineral (Dissanayake et al., 2009). Commercial ERP consists of both apatite and the matrix, containing 34.9-43.2 wt.\% $\mathrm{Ca}$ (Hewawasam et al.,1999). Percentages of $\mathrm{Ca}$ and $\mathrm{P}$ obtained were below the levels reported previously using X-ray diffractometry as the analytical method (Dahanayake et al.,1991, Hewawasam et al.,1999). This could be due to lower sensitivity of the XRF used in the study. $\mathrm{Cu}$ and $\mathrm{Sr}$ are naturally available in earth and can be assumed to be present in the apatite matrix. Early studies also indicate the presence of $3.3-11.9 \mathrm{wt} . \%$ $\mathrm{Fe}$ in secondary apatite and the matrix in the form of hematite $-\mathrm{Fe}_{2} \mathrm{O}_{3}$ (Dahanayake et al., 1991; 1995). The chemical analysis of ESSP shows a considerable amount of $\mathrm{S}$, since it is accumulated as $\mathrm{CaSO}_{4} \cdot 2 \mathrm{H}_{2} \mathrm{O}$ after acid treatment. In addition, $\mathrm{F}$ and $\mathrm{Cl}$ were not detected in the ESSP since it evolves into gases such as $\mathrm{HF}$ and $\mathrm{HCl}$, respectively during the acid treatment. 
After curing the product for a maximum (Gunawardena et al., 1994) of 4 weeks, the measured available $\mathrm{P}_{5} \mathrm{O}_{5}$ content of the product was $17.5 \mathrm{wt} \%$ agreeing with the similar result of $18 \%$ obtained in the study. It was also observed that the available phosphorus content of ESSP increases with increase in the extent of acidulation.

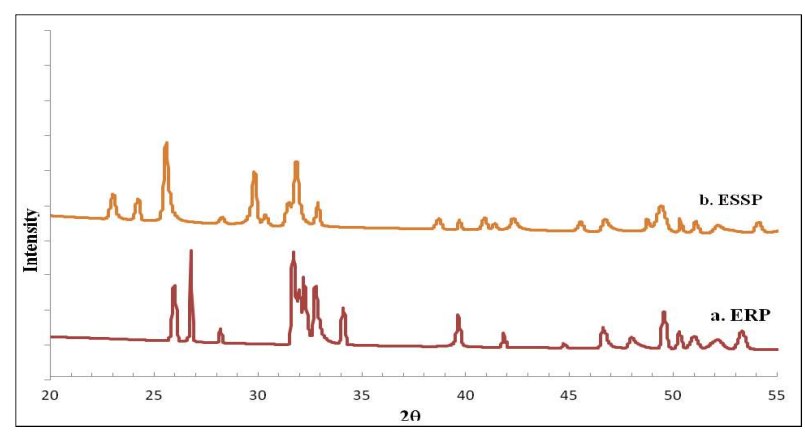

Figure 1: XRD patterns of initial raw material of ERP and the product of ESSP

XRD patterns of ERP and ESSP are given in Figure 1 ( $a$ and $b$, respectively). The XRD pattern of ERP can be attributed to hydroxyl apatite $\mathrm{Ca}_{10}(\mathrm{OH})_{2}\left(\mathrm{PO}_{4}\right)_{6}$ which is quite similar to that of the XRD pattern reported by Wimalasena et. al. (2009). XRD pattern for the ESSP reported first time in this study can be attributed to a completely new phase of mono calcium phosphate. However, anhydrate $\mathrm{CaSO}_{4}$ and gypsum - $\mathrm{CaSO}_{4} \cdot 2 \mathrm{H}_{2} \mathrm{O}$ also can be identified as major byproducts.

\section{Performance of ESSP in comparison to TSP at RRDI Batalagoda}

Table 1 shows the grain yield obtained in the experiment conducted at RRDI Batalagoda. There was no significant yield difference among four (4) treatments in the $1^{\text {st }}$ season, but a significant yield reduction was observed in the $2^{\text {nd }}$ and $3^{\text {rd }}$ seasons in the control plot. Even in the $4^{\text {th }}$ season there was no significant difference in yield between plots treated with TSP and ESSP at any rate. TSP treated plot produced the highest yield in $1^{\text {st }}, 3^{\text {rd }}$ and $4^{\text {th }}$ seasons followed by ESSP treated plots at the rates of 30 and $45 \mathrm{~kg} \mathrm{P}_{2} \mathrm{O}_{5} /$ ha, respectively. The lowest yield was recorded in the no-P plot. The initial soil $\mathrm{P}$ content of the site was $6 \mathrm{mg} / \mathrm{kg}$. The results are in agreement with the findings of IRRI (2000) that when the initial P level in the soil is below $10 \mathrm{mg} / \mathrm{kg}$ soil, there is a response to $\mathrm{P}$ application. In the $2^{\text {nd }}$ season, ESSP $45 \mathrm{~kg} \mathrm{P}_{2} \mathrm{O}_{5} /$ ha rate had a higher yield than TSP $45 \mathrm{~kg} \mathrm{P}_{2} \mathrm{O}_{5} /$ ha rate. It is clear from these results that there was a gradual reduction in the rice yield in the control plots treated with no $\mathrm{P}$ fertiliser. A similar reduction was not observed in the plots treated with TSP or the ESSP.

\section{Soil $P$ content}

The initial P level of the experiment site was $6 \mathrm{mg} / \mathrm{kg}$ of soil and it is clear that the rice yield is always higher in the plots treated with $\mathrm{P}$ fertiliser than no-P plots. A considerable variation was observed in the residual $\mathrm{P}$ content in soil after harvesting in the first two seasons (Table 2). Plots treated with ESSP at the rate of $45 \mathrm{~kg}$ $\mathrm{P}_{2} \mathrm{O}_{5} /$ ha had significantly higher soil $\mathrm{P}$ content at the time of harvesting $(7 \mathrm{mg} / \mathrm{kg})$ in the $1^{\text {st }}$ season, but in the $2^{\text {nd }}$ and $3^{\text {rd }}$ seasons TSP $45 \mathrm{~kg} \mathrm{P}_{2} \mathrm{O}_{5} /$ ha treated plots had higher soil $\mathrm{P}$ than all the other treatments followed by

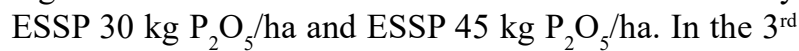
season, the difference in soil $\mathrm{P}$ contents among four (4) treatments was not significant, but soil $\mathrm{P}$ content in all 4 treatments were lower than that of $1^{\text {st }}$ and $2^{\text {nd }}$ seasons.

\section{Phosphorous content of plant samples at the time of harvesting}

The $\mathrm{P}$ content in plant samples showed larger variation among treatments (Table 2). Plant P content was higher in the plots treated with TSP while the lowest P content was recorded in the control plots without $\mathrm{P}$ fertiliser. Between the two ESSP rates, higher $\mathrm{P}$ content was recorded in plant samples in the plots treated with ESSP at the rate of $45 \mathrm{P}_{2} \mathrm{O}_{5} /$ ha. $\mathrm{P}$ content in the plant samples had a very good relationship with grain yields. When there was lower grain yield, $\mathrm{P}$ content of the plant was also lower and vice versa (Tables 1 and 2).

Table 3 shows that the application of $\mathrm{P}$ fertiliser increased the 1000 grains weight of rice as well as number of filled grains per panicle. However, the differences among $\mathrm{P}$ treatments are not significant.

\section{Performance of ESSP under farmer fields in Polonnaruwa}

The results show that grain yield among 5 treatments were almost similar in all the 3 locations in Polonnaruwa (Table 4). Yield at the Jayanthipura location was higher compared with the other two locations, while the lowest yield was recorded at Hingurakgoda. The initial soil $\mathrm{P}$ contents of the sites were $4.05,4.22$ and $2.22 \mathrm{mg} / \mathrm{kg}$ soil for Jayanthipura, Thopawewa and Hingurakgoda, respectively. Although the soil $\mathrm{P}$ levels are low, there was no yield difference between no-P plots and $\mathrm{P}$ - treated plots. 
Table 1: Mean grain yield ( $\mathrm{t} / \mathrm{ha})$ of rice after different $\mathrm{P}$ treatments: soil $\mathrm{P}$ content $(\% \mathrm{a})$ after each season at Batalagoda

\begin{tabular}{lccccccc}
\hline Treatment & \multicolumn{2}{c}{ Maha 2003/2004 } & \multicolumn{2}{c}{ Yala 2003 } & \multicolumn{2}{c}{ Maha 2004/2005 } & Yala 2004 \\
& $\begin{array}{c}\text { Grain } \\
\text { yield } \\
(\mathrm{t} / \mathrm{ha})\end{array}$ & $\begin{array}{c}\text { Soil P } \\
\text { content } \\
(\% \mathrm{a})\end{array}$ & $\begin{array}{c}\text { Grain } \\
\text { yield } \\
(\mathrm{t} / \mathrm{ha})\end{array}$ & $\begin{array}{c}\text { Soil P } \\
\text { content } \\
(\% \mathrm{a})\end{array}$ & $\begin{array}{c}\text { Grain } \\
\text { yield } \\
(\mathrm{t} / \mathrm{ha})\end{array}$ & $\begin{array}{c}\text { Soil P } \\
\text { content } \\
(\% \mathrm{a})\end{array}$ & $\begin{array}{c}\text { Grain } \\
\text { yield } \\
(\mathrm{t} / \mathrm{ha})\end{array}$ \\
\hline Control (No P fertiliser) & $4.17 \mathrm{~b}$ & 4.86 & $2.77 \mathrm{~b}$ & 6.42 & $3.23 \mathrm{~b}$ & 3.9 & $2.45 \mathrm{~b}$ \\
$45 \mathrm{~kg} \mathrm{P}_{2} \mathrm{O}_{5} \mathrm{ha}^{-1}$ as TSP & $5.51 \mathrm{a}$ & 3.81 & $4.22 \mathrm{ab}$ & 8.65 & $4.78 \mathrm{a}$ & 4.26 & $4.46 \mathrm{a}$ \\
$30 \mathrm{~kg} \mathrm{P}_{2} \mathrm{O}_{5} \mathrm{ha}^{-1}$ as ESSP & $4.78 \mathrm{a}$ & 4.26 & $3.46 \mathrm{ab}$ & 8.27 & $4.30 \mathrm{a}$ & 4.49 & $4.21 \mathrm{a}$ \\
$45 \mathrm{~kg} \mathrm{P}_{2} \mathrm{O}_{5} \mathrm{ha}^{-1}$ as ESSP & $5.13 \mathrm{a}$ & 6.85 & $3.01 \mathrm{ab}$ & 7.14 & $4.22 \mathrm{a}$ & 4.41 & $4.37 \mathrm{a}$ \\
$\mathrm{CV}(\%)$ & 6.34 & & 5.27 & & 7.26 & & 6.93 \\
\hline
\end{tabular}

Means followed by the same letter in a column are not significantly different at $5 \%$ level

Table 2: $\quad$ Mean plant $P$ content (\%) for different forms and levels of $P$ fertiliser application

\begin{tabular}{lccc}
\hline Treatment & $\begin{array}{c}\text { Maha } \\
2003 / 2004\end{array}$ & $\begin{array}{c}\text { Yala } \\
2004\end{array}$ & $\begin{array}{c}\text { Maha } \\
2004 / 2005\end{array}$ \\
\hline Control (No P fertiliser) & 0.02 & 0.015 & 0.015 \\
$45 \mathrm{~kg} \mathrm{P}_{2} \mathrm{O}_{5} \mathrm{ha}^{-1}$ as TSP & 0.05 & 0.032 & 0.026 \\
$30 \mathrm{~kg} \mathrm{P}_{2} \mathrm{O}_{5} \mathrm{ha}^{-1}$ as ESSP & 0.04 & 0.025 & 0.016 \\
$45 \mathrm{~kg} \mathrm{P}_{2} \mathrm{O}_{5} \mathrm{ha}^{-1}$ as ESSP & 0.04 & 0.029 & 0.018 \\
\hline
\end{tabular}

* These values obtained by a single sample.
Table 3: Mean 1000 grain weight and the number of filled grains/ panicle in Maha 2004/2005 season

\begin{tabular}{lcc}
\hline Treatment & $\begin{array}{c}\text { Mean1000 grain } \\
\text { wt }(\mathrm{g})\end{array}$ & $\begin{array}{c}\text { Number of filled } \\
\text { grains/panicle }\end{array}$ \\
\hline Control (No P fertilizer) & $15.67 \mathrm{a}$ & $140 \mathrm{a}$ \\
$45 \mathrm{~kg} \mathrm{P}_{2} \mathrm{O}_{5} \mathrm{ha}^{-1} \mathrm{TSP}$ & $16.03 \mathrm{~b}$ & $176 \mathrm{~b}$ \\
$30 \mathrm{~kg} \mathrm{P}_{2} \mathrm{O}_{5} \mathrm{ha}^{-1}$ as ESSP & $16.30 \mathrm{~b}$ & $166 \mathrm{~b}$ \\
$45 \mathrm{~kg} \mathrm{P}_{2} \mathrm{O}_{5} \mathrm{ha}^{-1}$ as ESSP & $16.73 \mathrm{~b}$ & $163 \mathrm{~b}$ \\
$\mathrm{CV}(\%)$ & 9.26 & 7.34 \\
\hline
\end{tabular}

Means followed by the same letter in a column are not significantly different at $5 \%$ level

Table 4: $\quad$ Mean Grain yield ( $t /$ ha) of rice after application of P treatments (A), Mean soil P content (\%) after harvesting(B), Mean plant $P$ content (\%) at the time of harvesting (C) at 3 locations in Polonnaruwa

\begin{tabular}{lccccccccc}
\hline Treatment & \multicolumn{3}{c}{ Jayanthipura } & \multicolumn{3}{c}{ Thopawewa } & \multicolumn{3}{c}{ Hingurakgoda } \\
& $\mathrm{A}$ & $\mathrm{B}$ & $\mathrm{C}$ & $\mathrm{A}$ & $\mathrm{B}$ & $\mathrm{C}$ & $\mathrm{A}$ & $\mathrm{B}$ & $\mathrm{C}$ \\
\hline Control (No P fertiliser) & $5.679 \mathrm{a}$ & 2.55 & 0.41 & $5.069 \mathrm{a}$ & 3.3 & 0.61 & $3.658 \mathrm{a}$ & 2.63 & 0.17 \\
$30 \mathrm{~kg} \mathrm{P}_{2} \mathrm{O}_{5}$ ha $^{-1}$ as TSP & $5.439 \mathrm{a}$ & 3.16 & 0.47 & $5.023 \mathrm{a}$ & 3.98 & 0.67 & $3.943 \mathrm{a}$ & 3.54 & 0.26 \\
$45 \mathrm{~kg} \mathrm{P}_{2} \mathrm{O}_{5} \mathrm{ha}^{-1}$ as TSP & $4.943 \mathrm{a}$ & 3.64 & 0.43 & $5.046 \mathrm{a}$ & 3.98 & 0.61 & $4.139 \mathrm{a}$ & 3.73 & 0.40 \\
$30 \mathrm{~kg} \mathrm{P}_{2} \mathrm{O}_{5}$ ha $^{-1}$ as ESSP & $5.625 \mathrm{a}$ & 3.09 & 0.54 & $5.038 \mathrm{a}$ & 4.22 & 0.59 & $3.897 \mathrm{a}$ & 2.98 & 0.28 \\
$45 \mathrm{~kg} \mathrm{P}_{2} \mathrm{O}_{5}$ ha $^{-1}$ as ESSP & $5.563 \mathrm{a}$ & 3.78 & 0.50 & $4.910 \mathrm{a}$ & 4.71 & 0.69 & $3.952 \mathrm{a}$ & 5.44 & 0.23 \\
$\mathrm{CV} \%$ & 10.35 & & & 11.45 & & & 9.68 & & \\
\hline
\end{tabular}

Means followed by the same letter in a column are not significantly different at $5 \%$ level

Table 5: Selected chemical characteristics of three experimental soils in the low country wet zone

\begin{tabular}{lccc}
\hline Chemical characteristics & Bombuwela & Palayangoda & Keenagasmanana \\
\hline Soil pH (1:2.4 Soil: $\left.\mathrm{H}_{2} \mathrm{O}\right)$ & 5.5 & 6.1 & 5.7 \\
$\mathrm{EC}(\mathrm{dS} / \mathrm{m})$ & 0.060 & 0.098 & 0.052 \\
$\mathrm{OM}(\%)$ & 12.0 & 7.2 & 7.8 \\
Exchangeable K $\left(\mathrm{mg} \mathrm{kg}^{-1}\right)$ & 90.1 & 46.0 & 56.0 \\
Olsen's P $\left(\mathrm{mg} \mathrm{kg}^{-1}\right)$ & 8.4 & 9.3 & 10.2 \\
\hline
\end{tabular}




\section{Soil $P$ content after harvesting}

There was a tendency to increase the soil $\mathrm{P}$ levels at the time of harvesting when plots were treated with $\mathrm{P}$ fertiliser (Table 4). Plots treated with ESSP at the rate of $45 \mathrm{~kg} \mathrm{P}_{2} \mathrm{O}_{5} /$ ha had the highest soil $\mathrm{P}$ at the time of harvesting followed by TSP $45 \mathrm{~kg} \mathrm{P}_{2} \mathrm{O}_{5} /$ ha. Plots treated with no $\mathrm{P}$ fertiliser recorded the lowest soil $\mathrm{P}$ at the time of harvesting.

\section{Plant $P$ content at maturity}

Plant $\mathrm{P}$ content varied among treatments in the same location and also in different locations as well. The location where the lowest soil $\mathrm{P}$ content was recorded (Hingurakgoda) had the lowest plant P content (Table 4).

\section{Field experiments in low country wet zone (LCWZ)}

Chemical characteristics of three different locations in the LCWZ given in Table 5 show that a considerable amount of available $\mathrm{P}$ present in the soil is available at all three locations. The effect of addition of ESSP on yield of rice in LCWZ is given in Table 6. Application of TSP at the rate of $30 \mathrm{~kg} \mathrm{P}_{2} \mathrm{O}_{5} / \mathrm{ha}$, and ESSP at rates of 14.4 and $30 \mathrm{~kg} \mathrm{P}_{2} \mathrm{O}_{5} /$ ha significantly increased the yield of rice over the control at RARDC, Bombuwala. Application of TSP at the rate of $30 \mathrm{~kg} \mathrm{P}_{2} \mathrm{O}_{5} /$ ha and ESSP at the rates of 14.4 and $30 \mathrm{~kg} \mathrm{P}_{2} \mathrm{O}_{5} /$ ha showed almost similar yields. However, at Palayangoda the rice crop did not show any significant yield response to the addition of $\mathrm{P}$ fertiliser. At Keenagasmanana, application of TSP at

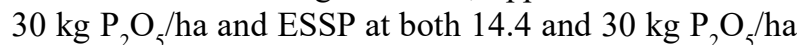
showed significantly higher yields than the control. TSP

Table 6: Effect of ESSP on: mean grain yield of rice (A); mean plant dry weight $\left(\mathrm{g} / \mathrm{m}^{2}\right)(\mathrm{B})$ and mean dry weight of roots $\left(\mathrm{g} / \mathrm{m}^{2}\right)(\mathrm{C})$ in the low country wet zone

\begin{tabular}{lccrrrrrrr}
\hline Treatment & \multicolumn{3}{c}{ Bombuwala } & \multicolumn{3}{c}{ Palayangoda } & \multicolumn{3}{c}{ Keenagasmanana } \\
& A & \multicolumn{1}{c}{ B } & C & A & B & C & A & B & C \\
\hline Control (No P fertiliser) & 2.38 & 119 & 12.8 & 2.13 & 376 & 63.6 & 2.62 & 399 & 54.5 \\
$30 \mathrm{~kg} \mathrm{P}_{2} \mathrm{O}_{5} \mathrm{ha}^{-1}$ as TSP & 3.00 & 142 & 28.1 & 3.02 & 554 & 90.8 & 3.48 & 632 & 72.2 \\
$7.2 \mathrm{~kg} \mathrm{P}_{2} \mathrm{O}_{5} \mathrm{ha}^{-1}$ as TSP & 2.52 & 120 & 21.5 & 2.43 & 428 & 76.9 & 2.83 & 482 & 57.2 \\
$10.8 \mathrm{~kg} \mathrm{P}_{2} \mathrm{O}_{5} \mathrm{ha}^{-1}$ as ESP & 2.63 & 142 & 23.3 & 2.60 & 443 & 85.6 & 2.97 & 567 & 65.3 \\
$14.4 \mathrm{~kg} \mathrm{P}_{2} \mathrm{O}_{5} \mathrm{ha}^{-1}$ as ESP & 3.03 & 165 & 28.3 & 3.12 & 510 & 89.2 & 3.47 & 637 & 73.0 \\
$30 \mathrm{~kg} \mathrm{P}_{2} \mathrm{O}_{5} \mathrm{ha}^{-1}$ as ESP & 3.08 & 169 & 34.9 & 3.18 & 568 & 93.4 & 3.52 & 639 & 75.1 \\
LSD $(\mathrm{p}=0.05)$ & 0.25 & $\mathrm{NS}$ & 5.0 & $\mathrm{NS}$ & 106 & $\mathrm{NS}$ & 0.37 & $\mathrm{NS}$ & $\mathrm{NS}$ \\
$\mathrm{CV}(\%)$ & 4.8 & 16.0 & 11.2 & 15.2 & 12.2 & 13.7 & 6.4 & 19.1 & 18.9 \\
\hline
\end{tabular}

Table 7: Effect of different $P$ sources on mean rice yield

\begin{tabular}{lcccc}
\hline Source of P & \multicolumn{4}{c}{ Mean rice yield (t/ha) } \\
& Yala 2003 & Maha 2003/2004 & Yala 2004 & Maha 2004/2005 \\
\hline Control (No P fertiliser) & 2.17 & 3.67 & 4.10 & 2.52 \\
ERP & 2.21 & 3.75 & 4.77 & 2.65 \\
HERP & 2.23 & 4.08 & 4.89 & 3.21 \\
ESSP & 2.28 & 4.30 & 5.40 & 4.68 \\
TSP & 2.33 & 4.46 & 5.37 & 4.73 \\
$50 \%$ TSP $+50 \%$ HERP & 2.28 & 4.60 & 5.15 & 3.81 \\
LSD (p=0.05) & NS & NS & 0.61 & 0.64 \\
CV (\%) & 4.7 & 14.7 & 6.8 & 9.8 \\
\hline
\end{tabular}


treatment and ESSP at rates 14.4 and $30 \mathrm{~kg} \mathrm{P}_{2} \mathrm{O}_{5} / \mathrm{ha}$ showed almost similar yields.

The effect of application of ESSP on dry weight of foliage is given in Table 6. Crops planted at RARDC, Bombuwala and Keenagasmanana locations did not show any significant increase in dry weight of plants due to addition of $\mathrm{P}$ fertilisers. However, application of TSP at the rate of $30 \mathrm{~kg} \mathrm{P}_{2} \mathrm{O}_{5} / \mathrm{ha}$ and ESSP at rates of 14.4 and $30 \mathrm{~kg} \mathrm{P}_{2} \mathrm{O}_{5} /$ ha resulted in significant increase in plant dry weight over the control. The highest plant dry weight was recorded in plots treated with ESSP at the rate of $30 \mathrm{~kg} \mathrm{P}_{2} \mathrm{O}_{5} /$ ha. However, application of TSP at $30 \mathrm{~kg} \mathrm{P}_{2} \mathrm{O}_{5} /$ ha ESP at 14.4 and $30 \mathrm{~kg} \mathrm{P}_{2} \mathrm{O}_{5} /$ ha showed significantly similar plant dry weight.

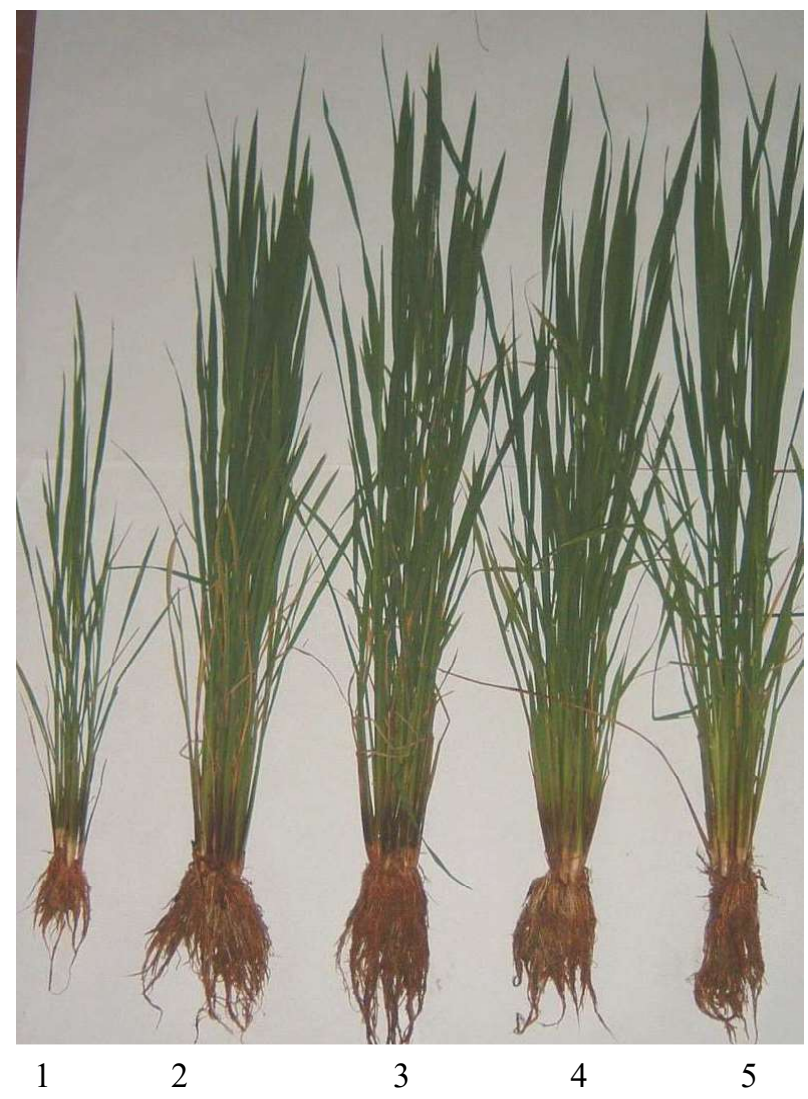

1. Control; 2. TSP $30 \mathrm{~kg} \mathrm{P}_{2} \mathrm{O}_{5}$ ha $^{-1} ; 3$. TSP $45 \mathrm{~kg} \mathrm{P}_{2} \mathrm{O}_{5}$ ha $^{-1} ; 4$. ESSP $30 \mathrm{~kg}$ $\mathrm{P}_{2} \mathrm{O}_{5} \mathrm{ha}^{-1}$ and 5. ESSP $45 \mathrm{~kg} \mathrm{P}_{2} \mathrm{O}_{5} \mathrm{ha}^{-1}$

Figure 2: Root development with application of TSP and ESSP and their different rates at Batalagoda.

The effect of ESSP on dry weight of roots is given in Table 6. Application of TSP and ESSP showed significantly higher root dry weight over the control
(Figure 2). However, the highest root dry weight was recorded in plots treated with ESSP at the rate of $30 \mathrm{~kg}$ $\mathrm{P}_{2} \mathrm{O}_{5} /$ ha followed by ESSP at the rate of $14.4 \mathrm{~kg} \mathrm{P}_{2} \mathrm{O}_{5} /$ ha; TSP at the rates of $30 \mathrm{~kg} \mathrm{P}_{2} \mathrm{O}_{5} / \mathrm{ha}$; ESSP at rates of 10.8 and $7.2 \mathrm{~kg} \mathrm{P}_{2} \mathrm{O}_{5} / \mathrm{ha}$, respectively. Rice crop at Palayangoda and Keenagasmanana did not show any significant increase in root dry weight with the addition of $\mathrm{P}$ fertilisers.

There was no significant response in plant height as well as root length to addition of $\mathrm{P}$ fertilisers at all three locations.

\section{Effect of $P$ sources on yield}

The effect of $\mathrm{P}$ sources on the yield of rice is shown in Table 7. In the Yala 2003 and Maha 2003/2004 seasons, rice did not show any significant yield response to the $\mathrm{P}$ sources. This may be due to the presence of $\mathrm{P}$ in the soil at the commencement of the experiment (Table 8). Initial soil $\mathrm{P}$ values present in the experimental soil could be considered as medium category according to DOA (1997). In the Yala 2004 season, application of all $\mathrm{P}$ sources showed significantly higher yields over the control. However, ERP and HERP gave almost similar yields. ESSP showed the highest yield followed by TSP, $50 \%$ TSP $+50 \%$ HERP, HERP and ERP. Application of HERP, ESSP, TSP and $50 \%$ TSP + $50 \%$ HERP showed significantly similar yields. In the Maha 2004/2005 season, no significant yield response was shown for application of ERP over the control. However, HERP applications gave a significantly higher yield over ERP. TSP showed the highest yield followed by ESSP, $50 \%$ TSP $+50 \%$ HERP, HERP and ERP. Application of ESSP and TSP gave similar yields.

Table 8: Selected chemical characteristics of the experimental soil

\begin{tabular}{lc}
\hline Chemical characteristic & Value \\
\hline Soil pH (1:2.5 Soil: $\left.\mathrm{H}_{2} \mathrm{O}\right)$ & 4.7 \\
Ec $(\mathrm{dS} / \mathrm{m})$ & 0.096 \\
OM $(\%)$ & 15.1 \\
Exchangeable K $\left(\mathrm{mg} \mathrm{kg}^{-1}\right)$ & 159.4 \\
Olsen's P $\left(\mathrm{mg} \mathrm{kg}^{-1}\right)$ & 12.0 \\
\hline
\end{tabular}

\section{Effect of $P$ sources on plant dry weight}

In the Yala and Maha seasons of 2003 and 2004/2005 respectively, rice crop did not show any significant increase of plant dry weight to the five sources of $\mathrm{P}$ 
application (Table 9). In the Maha 2003/2004 season, application of different $\mathrm{P}$ sources with the exception of ERP gave significantly higher plant dry weight over the control. However, HERP, ESSP, TSP and $50 \%$ TSP $+50 \%$ HERP gave similar plant dry weight when compared to the control. In the Maha season 2004/2005, application of ERP and HERP did not show significant increase in plant dry weight over the control. However, application of ESSP, TSP and $50 \%$ TSP $+50 \%$ HERP gave significantly higher plant dry weight than the control. Application of ESSP, TSP and $50 \%$ TSP $+50 \%$ HERP gave similar plant dry weight.

Table 9: Effect of different sources of $P$ fertilisers on mean plant dry weight

\begin{tabular}{lcccc}
\hline Source of P & \multicolumn{4}{c}{ Mean plant dry weight $\left(\mathrm{g} / \mathrm{m}^{2}\right)$} \\
& Yala 2003 & Maha 2003/2004 & Yala 2004 & Maha 2004/2005 \\
\hline Control (No P fertiliser) & 397 & 259 & 302 & 235 \\
ERP & 406 & 307 & 327 & 267 \\
HERP & 439 & 326 & 363 & 292 \\
ESSP & 449 & 341 & 416 & 353 \\
TSP & 464 & 359 & 414 & 386 \\
$50 \%$ TSP $+50 \%$ HERP & 451 & 353 & 403 & 316 \\
LSD (p $=0.05)$ & NS & 50 & NS & 70 \\
CV $(\%)$ & 15.6 & 8.6 & 15.1 & 12.5 \\
\hline
\end{tabular}

Table 10: Effect of different sources of $P$ fertilisers on mean root dry weight

\begin{tabular}{|c|c|c|c|c|}
\hline \multirow[t]{2}{*}{ Source of $\mathrm{P}$} & \multicolumn{4}{|c|}{ Mean root dry weight $\left(\mathrm{g} / \mathrm{m}^{2}\right)$} \\
\hline & Yala 2003 & Maha 2003/2004 & Yala 2004 & Maha 2004/2005 \\
\hline Control (No P fertiliser) & 64 & 60 & 71 & 25 \\
\hline ERP & 66 & 75 & 97 & 30 \\
\hline HERP & 80 & 74 & 107 & 38 \\
\hline ESSP & 81 & 74 & 157 & 50 \\
\hline TSP & 83 & 88 & 140 & 58 \\
\hline $50 \%$ TSP $+50 \%$ HERP & 82 & 81 & 136 & 41 \\
\hline $\operatorname{LSD}(p=0.05)$ & 12 & NS & 33 & 18 \\
\hline CV $(\%)$ & 8.3 & 22.9 & 15.3 & 24.9 \\
\hline
\end{tabular}

Table 11: Effect of different sources of $P$ fertilisers on root length

\begin{tabular}{lcccc}
\hline P source & \multicolumn{4}{c}{ Root length (cm) } \\
& Yala 2003 & Maha 2003/2004 & Yala 2004 & Maha 2004/2005 \\
\hline Control (No P fertiliser) & 14.4 & 13.3 & 12.1 & 10.2 \\
ERP & 16.6 & 15.0 & 13.0 & 10.5 \\
HERP & 16.8 & 15.4 & 13.7 & 12.0 \\
ESSP & 17.5 & 15.7 & 17.1 & 14.2 \\
TSP & 18.1 & 16.6 & 17.5 & 14.3 \\
$50 \%$ TSP $+50 \%$ HERP & 17.5 & 16.3 & 15.3 & 12.8 \\
LSD $(\mathrm{p}=0.05)$ & $\mathrm{NS}$ & $\mathrm{NS}$ & 1.5 & 2.4 \\
CV $(\%)$ & 9.6 & 10.1 & 5.4 & 10.9 \\
\hline
\end{tabular}




\section{Effect of P sources on root dry weight}

In Yala 2003, application of P sources gave significantly high root dry weight, except ERP over the control (Table 10). In general, HERP, ESSP, TSP and $50 \%$ TSP + 50\% HERP showed almost similar root dry weights. However, in Maha 2003/2004, application of P sources did not show any significant differences in root dry weight. In Yala 2004, rice crop showed significantly higher root dry weight with the application of HERP, ESSP, TSP and $50 \%$ TSP $+50 \%$ HERP when compared with the control. However, application of ESSP, TSP and $50 \%$ TSP + 50 $\%$ HERP did not show any significant differences in root dry weight. In Maha 2004/2005, application of ERP and HERP did not show any significant increases in root dry weight. Application of ESSP, TSP and $50 \%$ TSP $+50 \%$ HERP gave significantly higher root dry weight over the control. The highest root dry weight was recorded in the plots treated with TSP followed by ESSP, $50 \%$ TSP + 50 $\%$ HERP and ERP. However, application of ESSP, TSP and $50 \%$ TSP $+50 \%$ HERP did not show any significant differences in root dry weight in Maha 2004/2005.

Table 12: Effect of application of ESSP and TSP on grain yield of rice

\begin{tabular}{lccc}
\hline District & $\begin{array}{c}\text { Number } \\
\text { of } \\
\text { locations }\end{array}$ & $\begin{array}{c}\text { Mean yield (t/ha) } \\
\text { Plots treated } \\
\text { with ESSP }\end{array}$ & $\begin{array}{c}\text { Plots treated } \\
\text { with TSP }\end{array}$ \\
\hline Kegalle & 3 & 4.34 & 4.88 \\
Ratnapura & 4 & 4.90 & 5.05 \\
Galle & 6 & 6.12 & 5.57 \\
Kalutara & 10 & 3.13 & 3.06 \\
Kandy & 3 & 6.55 & 6.23 \\
Kurunegala & 2 & 5.24 & 5.47 \\
Hambanthota & 4 & 7.49 & 7.66 \\
Ampara & 4 & 6.10 & 5.88 \\
Polonnaruwa & 4 & 6.22 & 5.20 \\
Monaragala & 5 & 5.54 & 5.62 \\
Trincomalee & 3 & 5.63 & 6.09 \\
Anuradhapura & 4 & 4.84 & 5.46 \\
Kandy inter province & 8 & 4.84 & 5.46 \\
Mahaweli B & 2 & 4.64 & 5.49 \\
Mahaweli C & 4 & 5.08 & 6.07 \\
Mahaweli H & 2 & 5.60 & 5.66 \\
Walawa & 5 & 7.18 & 7.03 \\
\hline Mean & & 5.5 & 5.6 \\
\hline$*$ & & & \\
\hline
\end{tabular}

* DZ and IZ are considered together as high potential area for rice.

\section{Effect of $P$ sources on root length}

In both Yala 2003 and Maha 2003/2004, application of $P$ sources did not show significantly higher root length over the control (Table 11). However, in Yala 2004 and Maha 2004/2005, application of P sources such as HERP, ESSP, TSP and $50 \%$ TSP + $50 \%$ HERP showed a significant increase in root length when compared to the no-P treatment. In both these seasons, effectiveness of ERP was inferior to other P sources. However, ESSP, TSP and $50 \%$ TSP $+50 \%$ HERP showed similar root lengths.

\section{Effect of $P$ fertiliser sources on available soil $P$}

Soil analysis after each crop season showed that the available P (Olsen's) content of all the P treated plots was higher than that of the control plot. However, the increase of soil P to ERP application was insignificant compared to that of HERP, ESSP, TSP and $50 \%$ TSP + $50 \%$ HERP. In general, higher P contents were recorded in plots treated with TSP and ESSP.

\section{Pilot scale farmer field demonstrations}

The results of 146 field demonstrations conducted throughout the country clearly showed (Table 12) that the effect of ESSP (5.5 t/ha) was on par with that of TSP (5.6 t/ha). Although 146 demonstrated field experiments were conducted throughout the country, results were collected only from 73 locations (26 from the wet zone and 47 from dry and intermediate zones). Since these experiments were non-replicated large scale $(1 / 2$ ac) plots, data were not subjected to statistical analysis. Overall assessment showed that ESSP performed equally well as TSP both in wet and dry zones. Application of TSP and ESSP has shown similar results in rice cultivation. Direct application of ERP and HERP did not show any positive effect on increasing rice yield. However, the application of TSP, ESSP, 50 $\%$ TSP $+50 \%$ HERP, and $75 \%$ TSP $+25 \%$ HERP has shown a positive effect in increasing rice yields in the LCWZ. Farmer field demonstrations have shown that ESSP performance was on par with that of TSP.

These results clearly show that ESSP could be used as a source of $\mathrm{P}$ fertiliser for rice cultivation in Sri Lanka. Sulpher content in ESSP may have a positive effect in increasing the crop yield particularly in S-deficient sandy soils, mainly in the eastern region of the country. 


\section{CONCLUSIONS}

Application of TSP and ESSP has shown similar results in rice cultivation. Direct application of ERP and HERP did not show any positive effect on increasing rice yield. However, application of TSP, ESSP, $50 \%$ TSP $+50 \%$ HERP, and $75 \% \mathrm{TSP}+25 \%$ HERP has shown a positive effect in increasing rice yields in the LCWZ.

Farmer field demonstrations have shown that ESSP performance was on par with that of TSP.

These results clearly indicate that ESSP could be used as a source of $\mathrm{P}$ fertiliser for rice cultivation in Sri Lanka. In addition, $\mathrm{S}$ content in ESSP may have a positive effect in increasing crop yield, particularly in S deficient sandy soils mainly in the eastern region of the country.

\section{Acknowledgement}

This research was funded by the Lanka Phosphate Limited, Eppawala.

\section{REFERENCES}

Dahanayake K. \& Subasinghe S.M.N.D. (1991). Mineralogical, chemical and solubility variations in the Eppawala phosphate deposit of Sri Lanka - a case for selective mining for fertilizers. Fertilizer Research 28: 233-238. DOI: https://doi.org/10.1007/BF01049756

Dahanayake K., Ratnayake M.P.K. \& Sunil P.A. (1995). Potential of Eppawala apatite as a directly applied lowcost fertiliser for rice production in Sri Lanka. Fertilizer Research 41: 145-150. DOI: https://doi.org/10.1007/BF00750756

Dissanayake C.B. \& Chandrajith R. (2009). Phosphate mineral fertilizers, trace metal and human health. Journal of the National Science Foundation of Sri Lanka 37 (3): 153-165. DOI: $10.4038 /$ jnsfsr.v37i3.1219

Department of Agriculture (DOA) (2000). Soil Testing Service of the Department of Agriculture, Sri Lanka

Gunawardena R.P. \& Udawatte C.P. (1994). Partial acidulation of Eppawala apatite with nitric acid. Ceylon Journal of Science (Physical Science) 1(1): 21-28.

Hemachandra K.D.S.M \& Jayawardena P.V.S.D.G. (1988). Response of fertilizer in a rice-vegetable crop rotation in the Matale district. Tropical Agriculturist 144: 1-11.

Hewawasam T. \& Dahanayake K. (1999). A note on chemistry and mineralogy of apatite of Eppawala and Ridigama phosphate deposits. Sabaragamuwa University Journal 2: 61-67.

Jayawardena D. (1988). The Eppawala rock phosphate project. Economic Review 14: (6) 10-12.

Jeffery P.G. (1971) Chemical Methods of Rock Analysis. Pergamon Press, Oxford, UK.
Joseph K.D.S.M. (1986). The influence of topography on rice land productivity and its effect on nitrogen and phosphorus fertilization. Tropical Agriculturist 142: 69-76

Maraikar S., Nagarajah S. \& Loganathan P. (1983). Phosphorus sorption characteristics of some lowland rice soils of the mid-country wet zone of Sri Lanka. Tropical Agriculturist 139: $31-41$.

DOI: http://192.248.43.136/handle/1/2745

Nagarajah S, Jauffer M.M.M. \& Nizar B.M. (1979). Phosphorus studies in the low land rice soils of the mid country wet zone. Tropical Agriculturist 135: 1-22.

Nagarajha S. (1980). Fertilizer Research for Rice cultivation. International Rice symposium. 159-199.

National Science Foundation (1999). A Report for Optimal Use of Eppawala Rock Phosphate in Sri Lankan Agriculture, pp25. NSF Committee on Eppawala Phosphate, National Science Foundation, Maitland place, Colombo 07, Sri Lanka.

Ratnayake M.P.K., Kumaragamage D. \& Dahanayake K. (1994). Comparison of selectively mined apatite crystals and commercially available rock phosphate from Eppawala, as P fertilizer for flooded rice. Tropical Agriculture Research 6: $223-230$. DOI: http://dl.nsf.ac.lk/handle/1/11820.

Senanayake N. (1984). Varietal tolerance to phosphorus deficiency in wetland rice soils. Tropical Agriculturist 140: $69-86$.

Seneviratne Banda K.M.K.M.A., Kandaragama D.M.G. \& Ethakada P. (2002). Response of rice to added phosphorus on low humic clay soil under major irrigation in the Polonnaruwa district. Annual Symposium of the Sri Lanka Department of Agriculture 4: 95-109.

Sirisena D.N.P. \& Weerasinghe H.K.P.J. (2000). Phosphorus requirement for irrigated low land rice grown in Nonclassic Brown soils (NCB). Annual Symposium of the Department of Agriculture, Sri Lanka 2: 483

Wickramasinghe W.M.A.D.B. \& Wijewardena J.D.H. (2000). Soil and nutrient management for increasing soil fertility towards increased rice productivity in Sri Lanka. Annals of the Sri Lanka Department of Agriculture, Peradeniya 2: 465-482

Wijesundara S.M., Wickramasinghe W.M.A.D.B. \& Wijesundara C. (1993). Chemical and bio fertilizers for rice. In Rice congress. Department of Agriculture, Peradeniya. Sri Lanka. 73- 103.

Wijewardena J.D.H. \& Amarasiri S.L. (1990). Comparison of phosphate sources on growth of vegetables on an acid soil. Tropical Agriculturist 146: 67-66.

Wijewardena J.D.H., Kannagara J.B.K., Yohalingam P. \& Kannangara E.H. (1998). Status of selected chemical characteristics of rice soils in the low country wet zone. Proceedings of the 54th Annual Sessions, Sri Lanka Association for the Advancement of Science 1: 70-71.

Wijewardena J.D.H. (1998). Effect of phosphorus sources and levels with particular emphasis on selectively mined Eppawala rock phosphate on vegetable production. Journal of the National Science Council of Sri Lanka 26(2): 93-100. DOI: $10.4038 /$ jnsfsr.v26i2.3558 
Wijewardena J.D.H. (1999). Nutrient availability in the rice soils of upcountry intermediate zone. Sri Lankan Journal of Agricultural Science 36: 63-69.

Wimalasena R.D., Udawatte C.P. \& Ileperuma O.A., (2009).
Comparative acidulation studies of the matrix and the single crystals of Eppawala apatite and XRD identification of byproducts. Ceylon Journal of Science: Physical Sciences 15: 41-47 